\title{
AN OVERVIEW OF MAIN AURIFEROUS REGIONS OF BRAZIL
}

\author{
SÉRGIO LUIZ MARTINI
}

\begin{abstract}
RESUMO UM APANHADO SOBRE AS PRINCIPAIS REGIÕES A URÍFERAS DO BRASIL Considerando-se as regiões auríferas do Brasil com produção (1965-94) e reservas acima de 101 de metal e seus contextos geológicos, é possível afirmar que elas contêm alguns dos tipos de depósitos normalmente representados em escudos pre-cambrianos, além de outros, talvez menos comuns em outros escudos. Entre os primeiros estão depósitos mesotermais em greenstone belts e unidades a eles assemelhadas, disseminações em conglomerados ortoquartzíticos paleoproterozóicos, e depósitos hospedados em sedimentos, particularmente em seqüências turbidíticas meso- a neoproterozóicas. Entre os do segundo tipo, estão depósitos associados a seqüências de médio a alto grau metamórfico com ouro como sub- ou co-produto de sulfetos de cobre disseminados strata-bound, ou hospedados em metassedimentos paleoproterozóicos grafitosos e/ou manganíferos, e.g. itabiritos, ou ainda mostrando feições epizonais a epitermais mas localizados em contexto intraplaca de idade mesoproterozóica. Uma comparação geral entre as diferentes regiões sugere que aquelas que exibem a maior variedade de estilos de mineralização - isto é, de ambientes geológicos produtivos -parecem ser as mais ricas em ouro. Este talvez seja um aspecto significativo a ser considerado na tentativa de identificar províncias mais bem aquinhoadas em termos de conteúdo aurífero.
\end{abstract}

Palavras-chave: ouro, províncias, contexto geológico, pré-cambriano, faixa de rochas verdes, granitos e metassedimentos proterozóicos, tipos e estilos de mineralização, veios, depósitos primários

ABSTRACT Considering auriferous regions of Brazil carrying production (1965-94) plus reserves over 101 metal and their geological settings, it may be advanced that the regions contain some primary gold deposit types normally represented in Precambrian shields, and some others, perhaps less commonly found elsewhere. Among the former are mesothermal lodes in greenstone belts and the like, disseminations in Paleoproterozoic orthoquartzitic conglomerates, and sediment-hosted ores, particularly in deformed Meso- to Neoproterozoic turbidite sequences. The latter includes deposits associated with medium to high metamorphic grade sequences as by- or co-product gold of strata-bound disseminated copper sulfides, or hosted by Paleoproterozoic graphite- and/or manganese-bearing metasediments, e.g. itabirites, or yet showing epizonal to epithermal features but located in intra-plate setting of Mesoproterozic age. A broad comparison between the different regions suggests that those exhibiting the greater variety of mineralization styles - that is to say, of productive geological settings - appear to be richer in gold. This is perhaps a significant aspect to be considered in trying to identify better-endowed gold provinces.

Keywords: Gold, provinces, geological setting, Precambrian, greenstone belt, Proterozoic metasedimentary rocks and granites, mineralization types and styles, lodes, primary deposits

INTRODUCTION In order to study in a preliminary way the distribution of gold in Brazil, a group of areas containing measured reserves plus production (1965-94) over an arbitrary threshold of 101 metal was selected (Cf. Farina et al. 1996). These areas amount to 25 and were separated into groups A and B, carrying over 1001 and from 10 to 1001 metal, respectively. The areas were outlined by considering the clustering of gold occurrences in the vicinities of the deposits responsible for the gold tonnage, as shown on maps from CPRM databases. The areas delineated in this way may be seen as metallic domains in the sense that they contrast in gold content as compared with adjacent areas carrying little or no gold (Cf. Routhier 1984). It is clear, evidently, that the domains are real entities only if the quality of the reported reserves is good. This aspect, however, was not considered here, although it is conceivably critical in areas showing significant reserves but low production levels. On the other hand, the selected areas include, as one would expect, the main auriferous regions of Brazil and, certainly, many of those addressed in the present edition. In the selected group, hopefully, are also included the main areas of interest concerning the definition of gold provinces of the country and the study of regional distribution of the metal.

The areas under scope were plotted on a synoptic tectonic map and the main geological settings showing primary mineralization in each of them were tabled. A brief text follows, based partly on the table itself and focusing on the lithostratigraphic and structural localization of the gold. No attempt was made to describe any area in detail.

Due to the amount and diversity of information, the literature coverage is not complete, as will be clear from the very start to the experts in each of the areas treated here. That is to say, synthesis was preceded by partial analysis only, though, as already stressed, the most significant auriferous regions are duly included. With respect to areas carrying less than 101 gold, the reader can find compiled information directly on the map by Farina and co-authors (1996).

BRIEF ACCOUNT ON THE AURIFEROUS REGIONS The gold areas under scope are shown in figure 1 and their main primary gold-bearing geological settings are listed in Table I. For the sake of clearness, the map shows the well-established configuration for Late Proterozoic times, though older units may occur in the fold belts. Other synoptic tectonic maps may be found elsewhere, v.g. Almeida et al. (1981) and Delgado \& Pedreira (1995). The literature used to compile the table is shown in the reference list at the end of the text.

An overview of the gold areas is presented below. Some of the aspects showed in concise form in Tab. I are treated in more detail and briefly commented on.

Firstly, one notes a significant contribution of volcanic-sedimentary settings, those of greenstone belt nature in particular, to the general picture of distribution of the gold-bearing regions. Even in various cases where gold is won only from placers, this type of setting represents the main choice for a possible primary source of the metal. The principal deposits of primary gold in greenstone environment are in the Quadrilátero Ferrífero, Itapicuru and Crixás provinces.

Many of the famous gold deposits of the Quadrilátero Ferrífero are strata-bound. In the Nova Lima district, the main deposits are hosted in the Lapa Seca and Raposos formations. The former is made up by a massive to banded rock called lapa seca, consisting essentially of quartz and carbonate (Fe-dolomite, ankerite, siderite, calcite). The latter is an Algoma-type BIF and contains the four classic facies of this kind of unit. Both formations include intercalations of, and are overlain by, green schists. They are considered laterally equivalent chemical products, and grouped under the Metasedimentary Chemical Unit of the Nova Lima Group (Ladeira 1988). In terms of Nova Lima stratigraphy, the chemical unit is located between a lower metavolcanic, mafic-ultramafic unit, and an upper clastic unit, containing a rock record ranging from metarudites to graphitic metapelites. In the São Bento district, eastern Quadrilátero, gold is associated with the sulfide facies of the São Bento iron formation. This unit is located in the middle portion of a sequence of Nova Lima chlorite-schists. The latter is carbonatic and graphitic near its base, and contains subsidiary iron formation horizons (Abreu et al. 1988).

In the Paleoproterozoic granite-greenstone terranes of Itapicuru (Kishida et al. 1991, Mello et al. 1996), particularly significant are gold concentrations in the basal Mafic Volcanic Unit, made up essentially of tholeiitic metabasalts. Deformation is complex, multiphase and heterogeneous, with attending greenschist metamorphism, also complex and poly phasic. Regional shear zones developed parallel to bedding constitute important controls on the distribution of gold mineralization. The two main districts are Faixa Weber and Maria Preta. The former, located within the basal tholeiites, contains the main deposit of the region, Fazenda Brasileiro (Santos et al. 1988), which consists of quartz-albite-sulfide veins and associated breccias within a beddingparallel mylonitic zone affected by hydrothermal alteration. The host rock is a quartz-magnetite-chlorite-schist locally known as magnetic schist.

In the Crixás greenstone belt, gold mineralization is hosted in the Ribeirão das Antas Formation, the top unit of the local stratigraphy, which consists of graphite and chlorite-schists, chemical horizons and felsic metatuffs. A regional mylonitic zone (Magalhães et al. 1988) apparently controls the location of deposits. The Mina III deposit contains the most important reserves. According to Yamaoka \& Araújo (1988) and Thomson \& Fyfe (1990), Mina III consists of a lower zone, composed of metachert and/or siliceous breccia associated with a graphitic schist, and an upper zone, composed of massive sulfides 
(arsenopyrite-pyrrothite-chalcopyrite) enveloped by carbonate and sulfide-bearing, altered sericite-chlorite-schists. Fortes \& Nilson (1991) and Fortes \& Jost (1996) consider the lower zone a quartz vein, and recognize basic rocks and iron- and alumina-rich sedimentary rocks as protoliths of the superior zone. As to structure, the deposit is located in a zone of ductile deformation related to thrusts generated in Upper Proterozoic times, and the mineralization would therefore be significantly younger than the greenstone hosts. Age data of metamorphism and alteration minerals apparently confirm such observation (Fortes et al. 1996).,

The significant contribution of granite-greenstone terranes to the Brazilian gold reserves repeats a feature already known from shield areas of other continents. However, one interesting aspect in Brazil is that the temporal distribution of greenstone-related gold, as shown in Tab. I, is apparently diachronous, with mineralization interpreted either as Archaean or Paleoproterozoic in age and coeval with the host sequence, or as Proterozoic in age and superimposed onto Archaean hosts. Ladeira (1991) and Teixeira et ai. (1990) consider the first case, for instance, for the Quadrilátero Ferrífero and Itapicuru lodes, respectively. The second case is suggested for the Quadrilátero by Scarpelli (1991) and for Crixás by Thomson \& Fyfe (1990), and Fortes \& co-authors (1996). A similar superimposition seems to occur in the Alto Guaporé region (Ebert et al. 1996, Geraldes et al. 1996).

Still under the Archaean, especial mention should be made to the medium to high-grade volcanic-sedimentary sequences of the Itacaiúnas Supergroup (Docegeo 1988) in the Carajás region. Such sequences exhibit great petrographic diversity, besides stratigraphic sequence and lithologic association that make them different from greenstone belts. They host gold concentrations in the Salobo and Igarapé Bahia districts. In the former, the metal is a by-product of disseminated copper deposits, exemplified by Salobo 3A (Vieira et al. 1988) and Pojuca/Corpo Quatro (Saueressig 1988), and originally interpreted simply as exhalative ore bodies. At Igarapé Bahia, the ore results from lateritic concentration after copper sulfide protore (e.g. Mayer et al. 1990, Sachs \& Batista 1994). Salobo 3A is described by Lindenmayer et al. (1990) as a strata-bound deposit hosted in exhalative, silicate-facies iron formation metamorphosed to high grade and subjected to three post-metamorphic hydrothermal events. The last one of these is related to post-tectonic granites of Proterozoic age $(1.8 \mathrm{Ga})$ and would be responsible for extensional veins which carry gold and molybdenum and occur associated to the copper ores. Yet Huhn (1996) considers the possibility that the mentioned last hydrothermal event be the main mineralizing agent of the deposits as a whole, and suggests a geological model entirely related to an anorogenic environment (Cf. iron oxide type with associated $\mathrm{Cu}-\mathrm{Au}$; Hitzman et al. 1992, Oreskes \& Hitzman 1993). As one can see, this is a kind of concentration that does not fit in the usual pattern found in greenstone terranes and that will keep bringing in a good deal of controversy.

On the other hand, in the case of basal oligomitic conglomerates of Paleoproterozoic transgressive cover sequences, gold mineralization in Brazil follows the classical model of clastic gold derived from adjacent granite-greenstone terrain, as indicated for the deposits of the Moeda Formation, Quadrilátero Ferrífero (Renger et al. 1988, Minter et al. 1990), and the Jacobina Group, west of the Itapicuru region (Molinari \& Scarpelli 1988). It is worth mentioning, however, that the Paleoproterozoic age indicated for the granite-greenstone terrains of Itapicuru renders these terrains inadequate as gold sources for Jacobina. It should be also added that Milési et al. (1996) refuse the paleoplacer model for the Jacobina deposits and reinterpret them in the context of a hydrothermal epigenetic setting with strong structural control.

Other styles of gold mineralization are also associated to Paleoproterozoic sequences in Brazil. Among them are, in the Quadrilátero, disseminations in manganese-bearing itabirites (jacutingas) of Itabira, and in deformed tourmalinites or quartz-tourmaline lodes of Passagem de Mariana (Ladeira 1991, Sá 1990, Vial 1988); and in Carajás, disseminations in manganiferous and graphitic, brecciated sediments of Serra Pelada (Meireles \& co-workers 1982,1988) and hydrothermal veinlets hosted in chloritized shear zones of sandstones and gabbros at Águas Claras (Silva \& Villas 1996). The host sequence of Águas Claras, though constituting a cover to Archean terrains, would itself be late Archean in age (Dias et al. 1996). There is also the possibility that the rock sequence of Mariana be Archean as well (Vial 1988).

In the Tapajós and Juruena - Peixoto de Azevedo regions gold occurs associated with an epizonal to epithermal, anorogenic environment of Mesoproterozoic age. This is a quite unusual situation for gold deposits, as detailed below.
Gold in Tapajós has been historically won from placer deposits. In the last years, however, many primary gold showings have been discovered. These are mostly quartz veins, although disseminations and stockworks have also been reported (e.g. Faraco et al. 1996b). Wall rocks to mineralization are Mesoproterozoic anorogenic granites of the so-called Maloquinha Suite (Santos et al. 1975) and associated felsic volcanic, ignimbrites and sediments, besides rocks of older units. The latter include greenstones, non-metamorphosed mafic rocks, Paleoproterozoic granites of the Parauari type and basement gneisses (Pessoa et al. 1977, Bizinella et al. 1980), and, among these, the granitoids of the last two units are those which exhibit the majority of the gold showings.

In several occurrences, sericitization and silicification are important alterations, particularly in felsic environment. Where wall rocks are mafic types, as in the case of the Davi workings, an alteration assemblage located in cataclastic structures and consisting of calcite, chlorite, prehnite and adularia, along with albitized zones, has been described (Martini \& Dreher 1996a). The host rock is a diabase lacking regional metamorphism and exhibiting subhorizontal slickensides probably related to strike-slip faulting in brittle regime. The overall picture suggests propylitization in shallow crustal environment. A similar situation is described by Santos (1996) for the Mamoal area. Hydrothermal breccias, indicative of the same shallow environment referred to above, have also been described elsewhere in the region, as in the case of the Cuiú-Cuiú area (Dreher 1996). Sediments apparently lacking penetrative cleavage may also host mineralization, as in the Abacaxis area (Robert 1996). An epizonal to epithermal model, with deposits hosted in or related to Maloquinha-type anorogenic granites has been proposed for the region (Robert 1996, Martini \& Dreher 1996a,b, Leal et al. 1984, Cf. intrusion-related deposits, Sillitoe 1991). The alteration pattern points to adularia-sericite alteration systems (Cf. Heald et al. 1987). Regional faulting commonly exerts control over this style of mineralization by allowing emplacement of granites and channelling subsequent alteration fluids (e.g. White \& Hedenquist 1990). This type of control for the Tapajós primary gold occurrences was already indicated by Damasceno et al. (1992).

One of the interesting aspects of the above-mentioned model is that it includes mineralization in pre-Maloquinha units which were originally emplaced in catazone to mesozone levels and later on submitted to epizonal conditions. Other peculiar aspects are the quite old age for the type of deposit under scope and its association with anorogenic, platform magmatism. Intrusion-related epizonal to epithermal gold deposits are normally related to Cenozoic magmatism at active continental plate margins or in the adjacent portion of the oceanic environment.

Mineralization other than epizonal / epithermal seems also to be present in the region. Santos (1996), for instance, recognizes the incidence of ductile regimes in at least a few of the gold workings in the region (eg. Chico Torres, São José garimpos), and this situation, of course, has to be duly evaluated with respect to mesothermal-type gold. This type is predictable in the local greenstone and possible associated granites. The latter may be represented in the mentioned garimpos. Finally, it should also be reported that Faraco et al. (op. cit.) identified in the southeastern portion of the Tapajós region a sedimentary unit of conceivable Paleoproterozoic age, named Castelo dos Sonhos, which might represent another primary source of gold in the province.

The Juruena - Peixoto de Azevedo region is located south of the so-called Cachimbo graben, an ample trough of WNW-ESE direction filled by Proterozoic and Paleozoic sediments. Lineaments paralleling the graben margin constitute the main regional structures. North of the trough lies the Tapajós Province, whose main geological units are comparable to those of the region dealt with now.

Following the pattern of the Tapajós, the Juruena - Peixoto de Azevedo region also developed through alluvial deposits, as exemplified by the Alta Floresta district (Veiga 1988). Primary mineralization, though, has also been reported (eg. Yokoi 1994), particularly in association with anorogenic subvolcanic granites of the Teles Pires type of Silva et al. (1974). Felsic volcanic and pyroclastic rocks similar in age and geological setting to those of the Tapajós region are associated with these granites. Parauari-type granitoids have been identified in the vicinities of Alta Floresta and significant areas constituted by quartz-sericite-schists are found, according to Souza (1988), in basement domains of the Peixoto de Azevedo region.

At Juruena, western portion of the province, Yokoi (op. cit.) describes veins, veinlets and more seldom stockworks hosted by or related to Teles Pires type granites. As these are subvolcanic, the geological setting appears to be epizonal. The same setting is recog- 
nized by Araújo Neto \& Valente (1994) in the gold diggings of Peixoto do Azevedo, in the eastern half of the province, and includes veins in felsic volcanics (Souza 1988). These authors also report veins hosted in greenstones like talc and chlorite-schists, metacherts and metabasic rocks, as well as veins emplaced in basement granitoids. Part of these veins may possibly be mesothermal and part, repeating again the Tapajós, may be intrusion-related epizonal material hosted in rocks originally emplaced in deeper conditions.

A further aspect in Tab. I worth mentioning is the clustering of sediment-hosted gold 'deposits in the middle and upper Proterozoic The majority of them appears to be of mesothermal nature, located in altered shear zones generated in upper Precambrian thrust belts. In at least two cases, Cuiabá and Brusque, the relevant sedimentary sequences are of turbidite fades (eg. Pires et ai. 1986, Basei et ai. 1994). This aspect suggests a straight comparison with deposits in similar sedimentary environments recognized elsewhere in both Precambrian and Phanerozoic fold belts (Cf. turbidite-hosted gold deposits, Boyle 1986).

Primary mineralization in several gold diggings of the Cuiabá low lands, as described by Pires et ai. (op. cit.) and Santos (1984), occurs as veins hosted by pyritic phyllites which locally carry also magnetite, tourmaline or manganese oxide. At the Poconé workings, the former
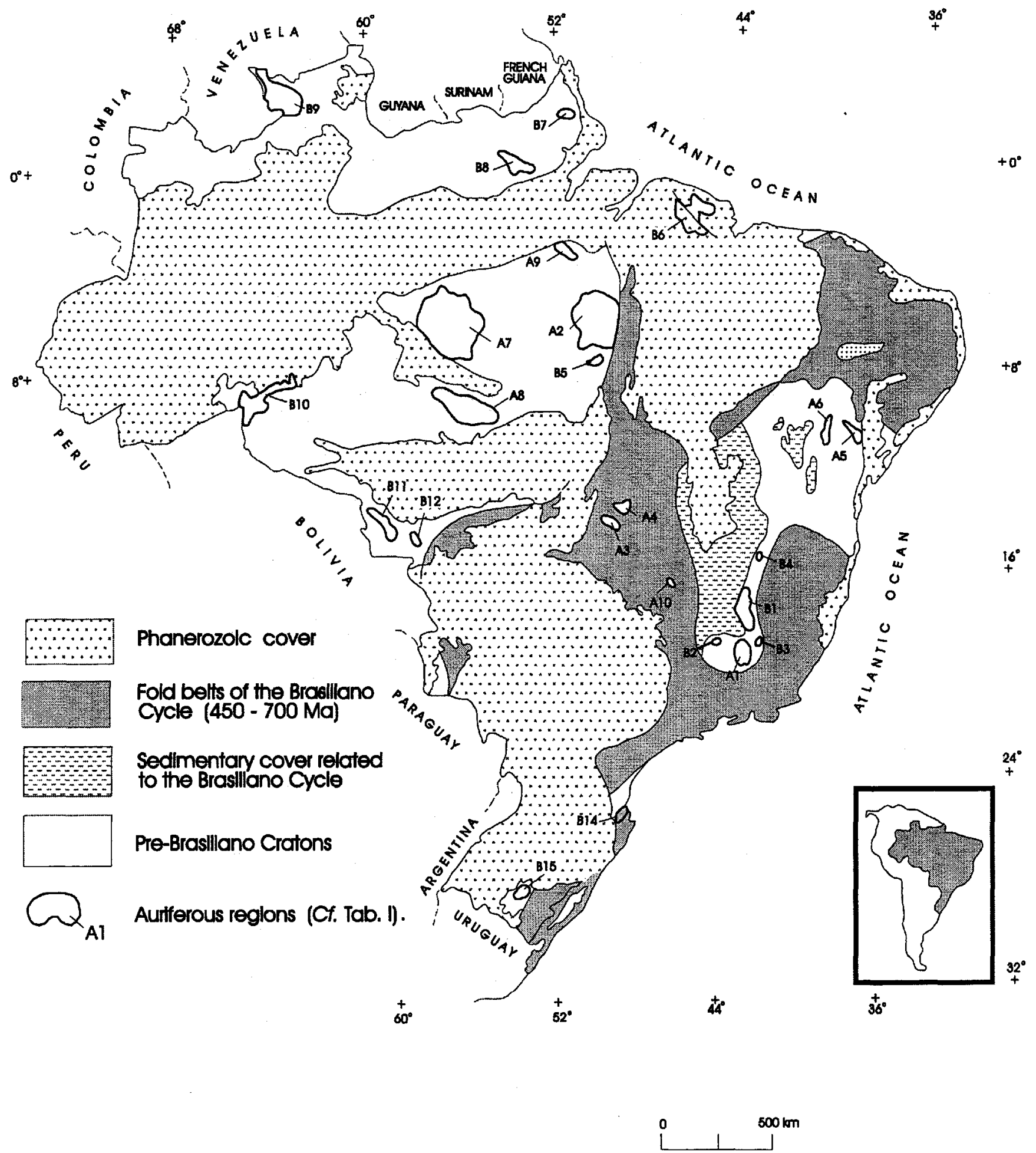

Figure 1 - Main auriferous regions of Brazil. Tectonic background after Schobbenhaus \& Campos (1984). 


\begin{tabular}{|c|c|c|}
\hline Gold Region & $\begin{array}{r}\text { Arch = Archean; PP, MP, NP = Paleo, Meso, Neoprotorezoic; EoP } \\
\text { Eo-Paleozoiczoic; GB Greenstone Belt, VSS Volcano-sedimentary } \\
\text { Sequence }(A>100>B>10 t \text { Au })\end{array}$ & References \\
\hline \multirow[t]{4}{*}{$\begin{array}{l}\text { A1 Quadrilátero } \\
\text { Ferrífero }\end{array}$} & $\begin{array}{l}\text { Arch GB: strata-bound (eg. Morro Velho) \& shear-hosted lodes (eg. } \\
\text { Tinguá) }\end{array}$ & $\begin{array}{l}\text { Uhlein et al. (1986), Pires et al. (1986), Santos et al. (1988), Abreu et al. } \\
\text { (1988), Ladeira (1988), Kuyumijan (1991) }\end{array}$ \\
\hline & $\begin{array}{l}\text { PP (or Arch?) metasediments: strata-bound tourmalinitic lodes } \\
\text { (Mariana) }\end{array}$ & Veiga (1985), Duarte \& Pires (1996), Figueiredo et al. (1996), \\
\hline & PP Rand-type disseminations in oligomictic conglomerates (Moeda) & Pires et al (1986), Minter et al (1990), Minter et al (1991), \\
\hline & $\begin{array}{l}\text { Disseminations in PP Mn-bearing Superior-type itabirites (Gongo } \\
\text { Soco) }\end{array}$ & Ladeira $(1988,1991)$ \\
\hline \multirow[t]{5}{*}{ A2 Carajás } & Arch GB: MT lodes and disseminations in greenschists (Andorinhas) & Nascimento \& Biagini (1988), Arantes et al. (1991), Sillitoe (1991) \\
\hline & and associated intrusive I-type granites (Cumaru, Gradaús) & Leonardos et al. (1991), Santos \& Reis (1992) \\
\hline & $\begin{array}{l}\text { Arch, high-grade VSS: subproduct of disseminated exhalative } \mathrm{Cu}- \\
\text { sulphides }\end{array}$ & $\begin{array}{l}\text { Lindenmayer et al. (1990), Huhn (1996), Lima \& Almeida (1996), Marques et } \\
\text { al. (1996) }\end{array}$ \\
\hline & plus epigenetic gold (Salobo, Pojuca) and in related gossans (Ig. Bahia) & Veiga (1988), Marques et al (1996), Santos (1997) \\
\hline & $\begin{array}{l}\text { Disseminated in Arch/PP altered (A Claras) or Mn-bearing sediments } \\
\text { (S. Pelada) }\end{array}$ & Silva et al. (1974), Mayer et al. (1990), Mayer et al. (1990), Dias et al. (1996) \\
\hline A3 Crixás & Arch GB with mesothermal NP lodes (eg. Mina III, Mina Nova) & $\begin{array}{l}\text { Macambira \& (1984), Teixeira et al. (1990), Viveiros (1991), Fortes \& Nilson } \\
\text { (1991), Fortes \& Jost (1996), Fortes et al. (1996), }\end{array}$ \\
\hline \multirow[t]{3}{*}{ A4 Mara Rosa } & High grade NP VS sequence: strata-bound epigenetic lodes (Posse), & Angeiras et al (1988), Aquino (1994) \\
\hline & lodes associated with volcanogenic massive sulphides (Zacarias) and & Angeiras et al (1988), Aquino (1994) \\
\hline & gold as subproduct of disseminated exhalative Cu-sulphides (Chapada) & Kuyumijan (1991), Silva \& Xavier (1996) \\
\hline \multirow[t]{2}{*}{ A5 Itapicuru } & PP GB: lodes hosted in magnetite-chorite-schist (Faixa Weber) and in & $\begin{array}{l}\text { Silva \& Sá (1988), Meireles \& Silva (1988), Kishida et al. (1991), } \\
\text { Santos \& Reis (1992), Silva \& Villas (1996) }\end{array}$ \\
\hline & carbonaceous phyllonites within sericite-chlorite-schists (Maria Preta) & GITEW/SUMEN-CVRD (1988), Kirchner (1986), Viveiros (1991) \\
\hline A6 Jacobina & PP Rand-type disseminations (with epigenetic component?) & Milési et al. (1996), Misi et al. (1993) \\
\hline \multirow[t]{3}{*}{ A7 Tapajós } & $\begin{array}{l}\text { Epizonal/epithermal veins and disseminations in MP anorogenic } \\
\text { granites }\end{array}$ & $\begin{array}{l}\text { Leal et al. (1984), Chaves \& Uhlein (1985), Docegeo (1988), Marques et al. } \\
\text { (1996) }\end{array}$ \\
\hline & $\begin{array}{l}\text { in associated ignimbrites, mafics and sediments(?), and in older } \\
\text { granitoids }\end{array}$ & $\begin{array}{l}\text { Santos et al. (1988), Santos et al. (1994), Martini \& Dreher (1996 b) } \\
\text { Ribeiro Rodrigues et al (1996) }\end{array}$ \\
\hline & Arch $\mathrm{GB}(?), \mathrm{PP}$ granites and mafic rocks: rare mesothermal lodes & Chaves \& Uhlein (1985), Santos et al. (1988), Bastos Leal \& Tassinari (1994) \\
\hline A8 Juruena / P. Azevedo & $\begin{array}{l}\text { Epizonal veins and stockworks in MP anorogenic granites and in } \\
\text { associated volcanics. Rarer mesothermal lodes in green schists(?) }\end{array}$ & $\begin{array}{l}\text { Uhlein et al. (1986), White \& Hedenquist (1990), ???? (1994), Soares et al. } \\
\text { (1994) }\end{array}$ \\
\hline A9 Bacajá & Lodes hosted in Arch VSS and PP granites & Scarpelli (1991), Aquino (1994), Cabral \& Pires (1996), Faraco et al. (1996a) \\
\hline A10 Paracatu & $\begin{array}{l}\text { NP, miogeoclinal, shallow-water sediments with (local) rhythmic } \\
\text { bedding: low-grade }(<1 \mathrm{~g} / \mathrm{t}) \text {, high tonnage, mesothermal, shear-related } \\
\text { mineralization }\end{array}$ & $\begin{array}{l}\text { Macambira \& (1984), White \& Hedenquist (1990), Teixeira et al. (1990), } \\
\text { Freitas Silva et al. (1991), Freitas Silva et al. (1996) }\end{array}$ \\
\hline B1 Serro & $\begin{array}{l}\text { Gold as subproduct of diamond-bearing gravels. Various types of } \\
\text { primary occurrences, including gold in Arch GB and in MP graphitic } \\
\text { phyllite }\end{array}$ & $\begin{array}{l}\text { Araújo et al. (1982), Toniolo \& Costa (1994), Toniolo \& Kirchner (1994), } \\
\text { Carvalho et al. (1994) }\end{array}$ \\
\hline
\end{tabular}




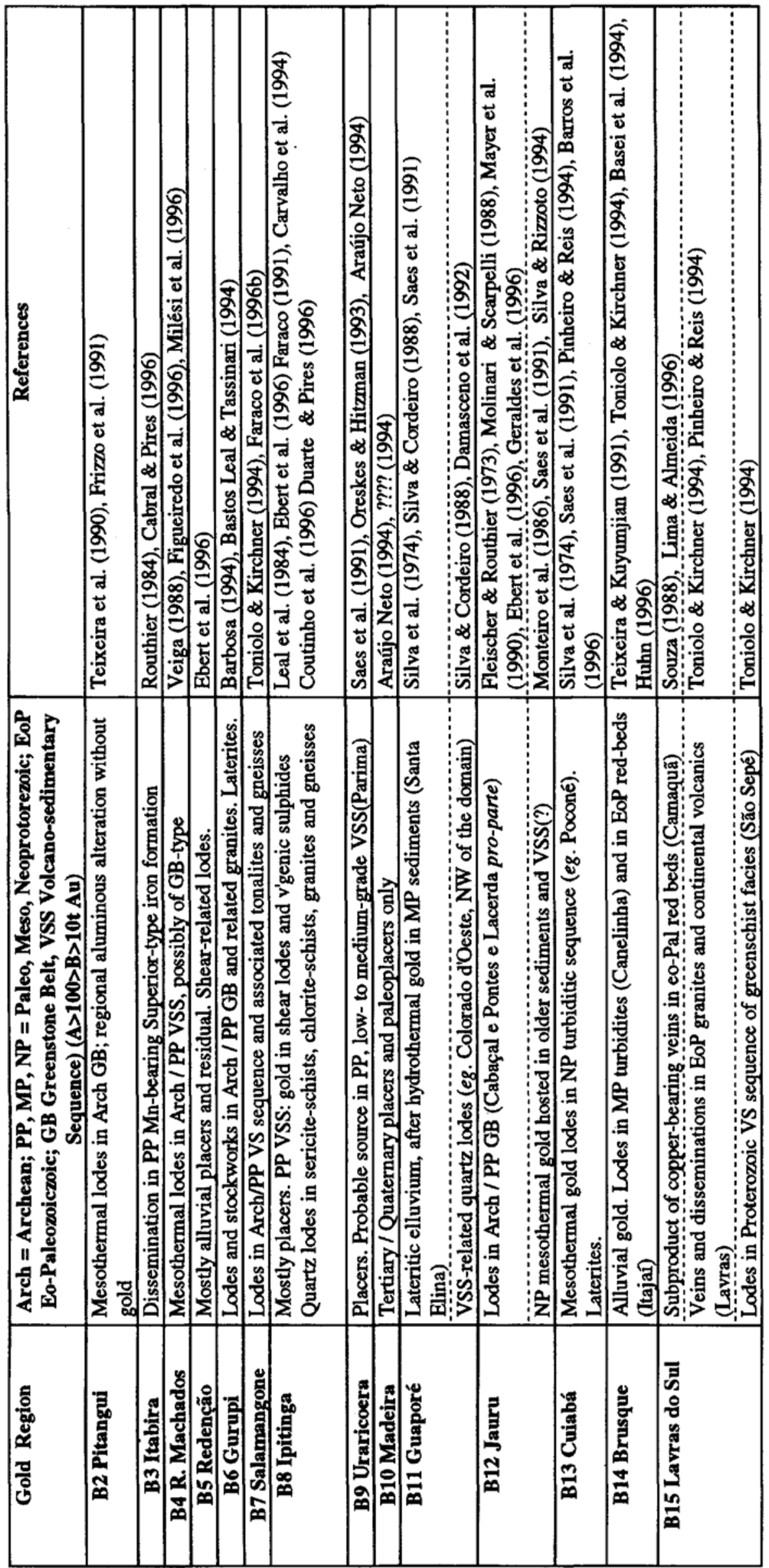


authors recognized two generations of veins, with the younger, discordant ones, normally bearing the bulk of the gold. In the same region, Barros et al. (1996) describe, in addition to veins, strata-bound mineralization in the form of swarms of veinlets in shear zones located in the hinges of recumbent folds. According to the latter authors, metasediments in mineralized sectors show pervasive potassic alteration, as exemplified by sericite enrichment, and haloes of pyrite, carbonate and magnetite near the veins and veined zones.

The gold showings of Canelinha, located $30 \mathrm{~km}$ southeast of Brusque, are described in some detail by Toniolo \& Costa (1994). Local geological setting consists of a sequence of metarhythmites with volcanic contribution, metamorphosed to greenschist facies and deformed in a low angle ductile regime as shown by a strong S2 foliation. Main rock types include graphitic phyllites, fine-grained quartzites, amphibolites, calc-silicate rocks, magnetite-biotite-quartz-schists and banded quartz-tourmalinites, besides rare intermediary metatuffs. The sequence is considered of Paleo to Mesoproterozoic age, and is intruded by younger granites. Primary gold showings are pyrite and arsenopyrite-bearing quartz veins and lenses distributed parallel to the main foliation. Besides these, strong pyrite and pyrrhotite disseminations occur in tourmalinites and, with accompanying chalcopyrite, in calc-silicate rocks with interbedded metabasic material.

The gold mineralization of the Aguapei Group, in Alto Guaporé, and Morro do Ouro, in Paracatu, is hosted in platform-type sequences and differs in this aspect of sedimentary environment from the abovementioned sediment-hosted deposits. The Aguapei Group, for instance, was generated in an intracratonic basin, and shows aeolic, braided and shallow marine facies (Saes et al. 1991). Morro do Ouro is also located in a shallow water marine sequence, in a miogeoclinal setting (Zini et al. 1988).

The Paracatu Formation contains the gold mineralization of Morro do Ouro and is made up mainly of graphitic phyllites with lenses and interbeds of impure sandstones. Rhythmically bedded clastic-chemical rocks indicating quiet depositional conditions also occur. Metamorphism is low grade. The specific ore-bearing lithology is described also as a carbonatic metarhythmite showing alternating light-coloured siltysandy bands and dark, graphitic clayey bands. The rock contains quartz boudins and all a variety of disseminated iron, arsenic and base metals sulfides, as well as gold, magnetite, ilmenite and hematite (Zini et al., op. cit., Marques et al. 1996). The deposit is peculiar in the aspect that the treated ores are very low-grade (ca. $0.6 \mathrm{~g} / \mathrm{t}$ ). Morro do Ouro may constitute an equivalent of the disseminated style of mineralization usually found in association with turbidites but hosted in a sequence deposited, according to Zini and co-workers, in a rather shallow water environment. Thorman et al. (1996), however, suggest that Morro do Ouro is similar to Carlin-type deposits.

Still dealing with the Neoproterozoic period, one should mention the gold deposits of the Mara Rosa region. The gold-bearing sequence in this case is somewhat similar to those of medium to high metamorphic grade of Carajás (e.g. Salobo) but radiometric ages recorded in each case are quite dissimilar, that is to say, lower (Carajás) versus upper Precambrian. At Mara Rosa, an association of gold mineralization with massive sulphides has been recognized for some small deposits, particularly in the case of Zacarias (Arantes et al. 1991). The main gold concentration, however, occurs in Chapada, where the metal occurs as by-product of strata-bound disseminated copper sulphides hosted in feldspathic quartzites and biotite-schists (Silva \& Sá 1988). Amphibolites and exhalites are found intercalated in these metassediments. Kuyumjian (1991) considers epidote-amphibolites with bands of epidosite found nearby the mineralized environs as possible feederzone material, and interprets the copper-gold deposit as an exhalative product. Further hydrothermal material includes pyritic quartzsericite-schists and aluminous, gedrite and staurolite-rich sulfidic rocks. The general style of mineralization, that is to say, strata-bound disseminated $\mathrm{Cu}-\mathrm{Au}$, resembles that of Salobo.

Lastly, mention should also be made to gold associated to red beds and continental volcanic rocks of Eo-Paleozoic age, in the regions of Gaspar - Itajaí and Lavras do Sul -Caçapava do Sul, southern Brazil. Subvolcanic rocks and granites, possibly related to the same overall geological setting, are also mineralized in the form of both veins and disseminations (Toniolo \& Kirchner 1994, Reischl 1980). At Minas do Camaquã, Caçapava do Sul, the alteration products which accompany auriferous copper sulfide veins were generated under epithermal conditions (Lima \& Almeida 1996).

CONCLUSIONS As a general conclusion, one may say that the regions herein under scope contain primary gold deposits representing types predictable in Precambrian shields, such as mesothermal lodes in greenstone belts and the like, disseminations in Paleoproterozoic orthoquartzitic conglomerates and sediment-hosted ores, particularly in deformed Meso- to Neoproterozoic turbiditic sequences. The first ones seem to be the most abundant. However, to the mentioned predictable styles other ones, perhaps less commonly found elsewhere, should be added. These include those associated with medium to high metamorphic grade sequences as by- or co-product of strata-bound disseminated copper sulphides, or hosted in Paleoproterozoic graphite-and/or manganese-bearing sediments, eg. itabirites, or yet showing epizonal to epithermal features but located in an intra-plate setting of Mesoproterozic age.

As a final statement, it is suggested that, in broad comparative terms, the regions exhibiting a relatively greater variety of mineralization styles appear to be richer in gold. This is particularly exemplified by considering the regions of the Quadrilátero Ferrífero and of Carajás as well as the pairs Crixás - Mara Rosa, Jacobina - Itapicuru and Guaporé - Jauru. This aspect seems to emphasize the importance of different gold-productive geological settings developing over the same region, and could perhaps be seen as a hint to better-endowed gold provinces.

Acknowledgments This article would not have been produced without the invaluable incentive of Jane Nobre-Lopes, Ana Maria Dreher and Sabino Loguercio, not to mention their critical reading of the manuscript. The author would like to express his deep gratitute to them. Erich Breitag contributed with his ability in digital drafting and his help is truly acknowledged herein. Thanks are due to Edilton José dos Santos, Gilberto Ramgrab and Eduardo Camozzato who also read the text and contributed to improve it.

\section{References}

Abreu, A.S.; Diniz, H.B.; Prado, M.G.B.; Santos, S.P. 1988. A mina de ouro de São Bento, Santa Bárbara, Minas Gerais. In: Schobbenhaus C. \& Coelho C.E.S. Coords. Principais depósitos minerais do Brasil, Volume III. Metais básicos não-ferrosos, ouro e alumínio. Brasília: DNPM. p. 393-411.

Almeida, F.F.M.; Hasui, Y.; Fuck, R.A. 1981. Brazilian structural provinces: An introduction. Earth Science Review, 17:1-29.

Angeiras, A.G.; Costa, L. A.M.; Santos, R.C. 1988. Depósito de ouro de Mara Rosa, Goiás. In: Schobbenhaus, C. \& Coelho, C.E.S. Coords. Principais depósitos minerais do Brasil. Volume III. Metais básicos não-ferrosos, ouro e alumínio. Brasília, DNPM, p. 523-534.

Aquino, E.G.T. 1994. Potencial aurífero da região da Volta Grande do rio Xingu, Área do rio Itatá -Estado do Pará. In: Congresso Brasileiro de Geologia, 38. Camboriú, 1994. Boletim de Resumos Expandidos... Camboriú, SBG. v. 2, p. 187-189.

Arantes, D.; Osborne, G.A.; Buck, P.S.; Porto, C.G. 1991. The Mara Rosa volcano-sedimentary sequence and associated gold mineralization. In: Ladeira, E. A. ed. Brazil Gold '91. Rotterdam, A.A. Balkema. p. 221-229.

Araújo, A.G.; Mello, M.P.; Litwinski, N; Martins, Jr. P.P. 1982. Principais recursos minerais do alto e médio vale do rio Jequitinhonha e alto rio Pardo - MG. In: Congresso Brasileiro de Geologia, 32. Salvador, 1982. Anais... Salvador, SBG. v. 3, p. $750-758$.

Araújo Neto, H. 1994. Tipologia dos depósitos auríferos da amazônia brasileira. In: Simpósio de Geologia da Amazônia, 4. Belém, 1994. Boletim de Resumos Expandidos...Belém, SBG. p. 69-71.
Araújo Neto, H. \& Valente, C.R. 1994. Mineralizações de ouro na região de Peixoto de Azevedo. In: Congresso Brasileiro de Geologia, 38. Camboriú, 1994. Boletim de Resumos Expandidos... Camboriú, SBG. v. 1, p. 170-171.

Barbosa, A.J. 1994. O Programa Nacional de Prospecção de Ouro na Região Nordeste: caracterização e gitologia dos jazimentos auríferos. In: Congresso Brasileiro de Geologia, 38. Camboriú, 1994. Boletim de Resumos Expandidos... Camboriú, SBG. v. 1, p. 321-322.

Barros, A.J.P.; Silva, G.D.; Oliveira, L.J.; Barreto, L.B.; Rodrigues, M.D. 1996. Estágio atual da exploração mineral e das práticas de controle ambiental nos garimpes de ouro da região de Poconé. In: Congresso Brasileiro de Geologia, 39. Salvador, 1996. Anais... Salvador, SBG. v. 3, p. 99-102.

Basei, M.A.S.; Campos Neto, M.C.; Siga Jr., O. 1994. Geologia do Grupo Brusque na região de Canelinha, SC. In: Congresso Brasileiro de Geologia, 39. Salvador, 1996. Anais... Salvador, SBG. v. 3, p. 243-244.

Bastos, J.B.S. 1988. Depósitos de ouro do rio Madeira, Rondônia. In: Schobbenhaus, C. \& Coelho, C.E.S. Coords. Principais depósitos minerais do Brasil. Volume III. Metais básicos não-ferrosos, ouro e alumínio. Brasília, DNPM, p. 575-580.

Bastos Leal, L.R. \& Tassinari, C.C.G. 1994. Características das mineralizações auríferas filoneanas dos garimpes do Creporizinho e Creporizão, Província Aurífera do Tapajós -PA. In: Congresso Brasileiro de Geologia, 38. Camboriú, 1994. Boletim de Resumos Expandidos... Camboriú, SBG. v. 1, p. 285-286.

Bettencourt, J.S.; Borges, W.R.; Koritiake, M. 1991. The Cachoeira gold deposit, Gurupi Belt, Pará, Brazil: Geological setting, structure and mineralization - A preliminary report. In: Ladeira, E.A. ed. Brazil Gold '91. Rotterdam, A.A. Balkema. p. 203-208. 
Bizinella, G.A.; Santiago, A.F.; Santos, A.; Borges, F.R.; Souza, F.J.C.; Godoy, H.K. Yamaguti, H.S.; Oliveira, J.R.; Oliveira, R.L. 1980. Projeto Tapajós -Sucunduri Relatório Final., Manaus, CPRM / DNPM, 2 v., 700 p.

Boyle, R.W. 1986. Gold deposits in turbidite sequences: Their geology, geochemistri and history of the theories of their origin. In: Keppie, J.D. et al. eds. Turbidite-hosted gold deposits. Geol. Assoc. Can. Special Paper 32, p. 1-13.

Cabral, A.R. \& Pires, F.R.M. 1996. On the metallogenesis of gold in the Lower Proterozoic Itabira iron-formation, Quadrilátero Ferrífero, Minas Gerais. In: Congresso Brasileiro de Geologia, 39. Salvador, 1996. Anais... Salvador, SBG. v. 7, p. 237-240. Carvalho, J.M.A.; Silva Neto, C.S.; Klein, E.L.; Faraco, T.L.F. 1994. Características da principais mineralizações auríferas no Pará e Amapá. In: Congresso Brasileiro de Geologia, 38. Camboriú, 1994. Boletim de Resumos Expandidos... Camboriú, SBG v. 1, p. 286-289.

Chaves, M.L.S.C. \&Uhlein, A. 1985. Dados preliminares sobre a geologia e mineralizações do Distrito Aurífero de Diamantina - MG. In: Simpósio de Geologia de Minas Gerais, 3. Belo Horizonte, 1985. Anais...Belo Horizonte, SBG. p. 264-275. Coutinho, M.G.N.; Dreher, A.M.; Martini, S.L. 1996. Controle das mineralizações de ouro na Província Mineral do Tapajós. In: Congresso Brasileiro de Geologia, 39. Salvador, 1996. Anais... Salvador, SBG. v. 7, p. 230-233.

CPRM \& MTA (Companhia de Pesquisa de Recursos Minerais / Mineração Transamazônica Ltda). 1994. Relatório Final de Pesquisa de Ouro. DNPMs $850.610 / 84,850.61$ í $3 / 84,850.614 / 84,850.681 / 84,850.682 / 84,851.215 / 85$, 851.216/85, 851.217/85. Belém, DNPM, 53 p.

Damascene, B.C.; Conceição A.L.; Amaral J.A.F.; Ricci P.S.F.; Pastana J.M.N.; Santos A.; Souza A.M.M. 1992. Projeto Ouro e Gemas. Relatório de Progresso I. Belém, CPRM, $67 \mathrm{p}$.

Delgado, LM. \& Pedreira, A.J. (Coords.). 1995. Mapa tectono-geológico do Brasil. Escala 1:7.000.000. Brasília, CPRM

Dias, G.S.; Macambira, M.J.B.; Dall'Agnol, R.; Soares, A.D.V.; Barros, C.E.M. 1996. Datação de zircões de sill de metagabro: Comprovação de idade arqueana da Formação Águas Claras, Carajás, Pará. In: Simpósio de Geologia da Amazônia, 5. Belém, 1996. Boletim de Resumos Expandidos... Belém, SBG. p. 376-379.

Docegeo. 1988. Revisão litoestratigráfica da Província Mineral de Carajás. In: Congresso Brasileiro de Geologia, 35. Belém, 1988. Província Mineral de Carajás -Litoestratigrafia e principais depósitos minerais. Belém, SBG. p. 9-54.

Dreher, A.M. 1996. Garimpos N.S. da Conceição, Cuiú-Cuiú e Bom Jesus: Relatório de Petrografia. Rio de Janeiro, CPRM, 23 p., 79 descrições petrográficas.

Duarte, B.P. \& Pires, F.R.M. 1996. On the origin of tourmaline in the Passagem gold-tourmaline deposits, Q.F. -MG. In: Congresso Brasileiro de Geologia, 39.

Salvador, 1996. Anais... Salvador, SBG. v. 7, p. 193-194.

Ebert, H.D.; Villanova, M.T.; Teixeira, J.T.; Ferron, J.M.T.M. 1996. Controle estrutural dos veios de quartzo auríferos em zonas de cisalhamento a sudeste de Colorado d'Oeste-RO. In: Congresso Brasileiro de Geologia, 39. Salvador, 1996. Anais... Salvador, SBG. v. 7, p. 213-217.

Faraco, M.T.L. 1991. Evolução petrológico-geoquímica das rochas da Suíte Metamórfica Vila Nova, na Serra do Ipitinga (NW do Pará). Belém. 346 p. (Dissertação de Mestrado, Instituto de Geociências da Universidade Federal do Pará).

Faraco, M.T.L. 1997. Evolução petroquímico-metalogenética das rochas e mineralizações associadas à Suíte Vila Nova na Serra do Ipitinga (NW do Pará). Belém. 193 p.

(Tese de Doutorado, Universidade Federal do Pará).

Faraco, M.T.L.; Carvalho, J.M.A.; Klein, E.L. 1996a. Carta Metalogenética da Província de Carajás / SE do Pará, Folha Araguaia. Escala 1:1.000.000. Belém, CPRM

Faraco, M.T.L.; Carvalho, J.M.A.; Klein, E.L. 1996b. Carta Metalogenética da Província Aurífera do Tapajós. Escala 1:500.000. Belém, CPRM

Farina, M.; Matos, G.M.M.; Araújo Neto, H.; Menezes, R.G. et al. 1996. Mapa de reservas e produção de ouro do Brasil. Escala 1:7.000.000. Brasília, CPRM.

Ferran, A. 1988. Depósito de ouro de Salamangone e Mutum, Calçoene, Amapá. In:

Schobbenhaus C. \& Coelho C.E.S. Coords. Principais depósitos minerais do Brasil.

Volume III. Metais básicos não-ferrosos, ouro e alumínio. Brasília, DNPM, p. 581-588.

Figueiredo, B.R.; Geraldes, M.C.; Ebert, H.G. 1996. Gold deposits in the Pontes \& Lacerda region, SW of Amazonian Craton, Brazil. In: Congresso Brasileiro de Geologia, 39. Salvador, 1996. Anais... Salvador, SBG. v. 7, p. 195-198.

Fleischer, R. \& Routhier, P. 1973. The co-sanguineous origin of a tourmaline-bearing gold deposit: Passagem de Mariana, Brazil. Economic Geology, 68:11-22.

Fonseca, E.; Guimarães, P.J.; Dutra Leal, E.; Medeiros Silva, H. 1991. The Ouro Fino gold Deposit, Minas Gerais, Brasil. In Ladeira, E. A. ed. Brazil Gold '91. Rotterdam, A. A. Balkema. p. 499-505.

Fortes, P.T.F.O. \& Nilson, A.A. 1991. Geologia do depósito aurífero Mina HI, Crixás, Goiás. In: Simpósio de Geologia do Centro-Oeste, 3. Cuiabá, 1991. Anais... Cuiabá, SBG/CO. p. $1-14$

Fortes, P.T.F.O. \& Jost, H. 1996. Metallogeny of Mina III, Mina Nova and Mina Inglesa gold deposits, Crixás greenstone belt, Central Brazil. In: Congresso Brasileiro de Geologia, 39. Salvador, 1996. Anais... Salvador, SBG. v. 7, p. 234-236.

Fortes, P.T.F.O.; Cheilletz, A.; Giuliani, G. 1996. K/Ar and Ar/Ar geochronology of Mina III gold deposit, Crixás greenstone belt, Central Brazil. In: Congresso Brasileiro de Geologia, 39. Salvador, 1996. Anais... Salvador, SBG. v. 7, p. 316-318.

Freitas Silva, F.H.; Dardenne, M.A.; Jost, H. 1991. Lithostructural control of the Morro do Ouro, Paracatú, Minas Gerais, gold deposit. In Ladeira, E. A. ed. Brazil Gold '91. Rotterdam, A.A. Balkema. p. 681-683.

Freitas Silva, F.H.; Dardenne, M.A.; Marques, F.R.P.M. 1996. Metalogênese do depósito do Morro do Ouro, Paracatú. In: Congresso Brasileiro de Geologia, 39. Salvador, 1996. Anais... Salvador, SBG. v. 7, p. 207-209.

Frizzo, C.; Takai, V.; Scarpelli, W. 1991. Auriferous mineralization at Pitangui, Minas Gerais. In Ladeira, E.A. ed. Brazil Gold '91. Rotterdam, A.A. Balkema. p. 579-583. Geraldes, M.C.; Figueiredo, B.R.; Tassinari, C.C.G. 1996. K/Ar and Pb/Pb isotopic studies of gold deposits in the Pontes e Lacerda region, SW of Amazonian Craton, Brazil. In: Congresso Brasileiro de Geologia, 39. Salvador, 1996. Anais... Salvador, SBG. v. 7 , p. $310-313$

GITEW/SUMEN-CVRD. 1988. Jazida de ouro da Fazenda Maria Preta, Santa Luz, Bahia. In Schobbenhaus C. \& Coelho C.E.S. Coords. Principais depósitos minerais do Brasil, Volume III. Metais básicos não-ferrosos, ouro e alumínio. Brasília, DNPM, p. $445-461$.
Heald, P.; Foley, N.K.; Hayba, D.O. 1987. Comparative anatomy of volcanic-hosted epithermal deposits: acid-sulfate and adularia-sericite types. Economic Geology, 82:1-26.

Hitzman, W.M.; Oreskes, N.; Enaudi, M.T. 1992. Geological characteristics and tectonic setting of Proterozoic iron oxide (Cu-U-Au-REE) deposits. Precambrian Research, 58:241-287.

Huhn, S.R.B. 1996. São os depósitos cupríferos de Carajás do tipo Cu-Au-U-(ETR)? In: Simpósio de Geologia da Amazônia, 5. Belém, 1996. Boletim de Resumos Expandidos...Belém, SBG., p. 140-143.

Kirchner, C. A. 1986. Prospecção aluvionar para ouro no rio Itajaí-Mirim, SC. In: Congresso Brasileiro de Geologia, 34. Goiânia, 1986. Anais... Goiânia, SBG. v. 5, p. 2355-2366.

Kishida, A.; Sena, F.O.; Silva, F.C.A. 1991. Rio Itapicuru greenstone belt: Geology and gold mineralization. In: Ladeira, E.A. ed. Brazil Gold '91. Rotterdam, A.A. Balkema. p. 49-59.

Kuyumijan, R.M. 1991. A suggested hydrothermal exhalative origin for the Chapada copper-gold deposit, Brazil. In: Ladeira, E.A. ed. Brazil Gold '91. Rotterdam, A.A. Balkema. p. 231-234.

Ladeira, E.A. 1988. Metalogenia dos depóstis de ouro do Quadrilátero Ferrífero, Minas Gerais. In: Schobbenhaus, C. \& Coelho, C.E.S. Coords. Principais depósitos minerais do Brasil, Volume III. Metais básicos não-ferrosos, ouro e alumínio. Brasília, DNPM, p. 301-375

Ladeira, E.A. 1991. Genesis of gold in Qaudrilátero Ferrífero: a remarkable case of permanency, recycling and inheritance - A tribute to Djalma Guimarães, Pierre Routhier and Hans Ramberg. In: Ladeira, E. A. (ed.), Brazil Gold '91. Rotterdam, A.A. Balkema. p. 11-30.

Leal, J.W.L.; Silva, J.J.X.; Matos, S.H.S. 1984. Ouro do Tapajós - Aspectos da geologia e mineralização. In: Congresso Brasileiro de Geologia, 33. Rio de Janeiro, 1984 Anais... Rio de Janeiro, SBG. v. 8, p. 3970-3982.

Leonardos, O.H.; Santos, M.D.; Giuliani, F.; Araújo, L.R. 1991. The Cumaru mesothermal granodiorite-hosted gold mineralization, Amazon craton, Brazil. In: Ladeira, E.A. (ed.), Brazil Gold '91. Rotterdam, A.A. Balkema. p. 557-562.

Lima, L. \& Almeida, D.P.M. 1996.0 jazimento epitermal de Minas do Camaquã e jazida Santa Maria (RS): Contribuição à petrografia e geotermometria. In: Congresso Brasileiro de Geologia, 39. Salvador, 1996. Anais... Salvador, SBG. v. 3, p.280-283.

Lindenmayer, Z.G.; Fyfe, W.S.; Machado, N. 1990. Alteração hidrotermal da formação ferrifera do depósito de cobre do Salobo, Estado do Pará. In: Congresso Brasileiro de Geologia, 36. Natal, 1990. Boletim Resumos...Natal, SBG. p. 104-105.

Lindenmayer, Z.G. \& Fyfe, W.S. A origem da formação ferrifera do deposto de cobre do Salobo, Estado do Pará. In: Congresso Brasileiro de Geologia, 36. Natal, 1990 Boletim Resumos... Natal, SBG. p. 109-110.

Macambira, E.M.B. \& Silva, J.J.S. 1984. Distrito aurífero da Serra do Ipitinga - Estado do Pará. In: Congresso Brasileiro de Geologia, 33. Rio de Janeiro, 1984. Anais... Rio de Janeiro, SBG. v. 8, pg 3959-3969.

Magalhães, L.F.; Lobo, R.L.M.; Botelho, L.C.A.; Pereira, R.C. 1988. Depósito de ouro de Meia-Pataca, Crixás - GO. In: Schobbenhaus C. \& Coelho C.E.S. Coords. Principais depósitos minerais do Brasil, Volume III. Metais básicos não-ferrosos, ouro e alumínio. Brasília, DNPM, p. 499-522.

Marques, F.B.; Batelochi, M.A.; Mõller, J.C.C. 1996. Geologia, mineralização e lavra do Morro do Ouro -Paracatú (MG). In: Congresso Brasileiro de Geologia, 39. Salvador, 1996. Anais... Salvador, SBG. v. 7, p. 204-206.

Martini, S.L. \& Dreher, A.M. 1996a. Visita aos garimpos Batalha e do Davi - Dados geológicos e petrográficos. Rio de Janeiro, CPRM, 4 p., 12 descrições petrográficas.

Martini, S.L. \& Dreher, A.M. 1996 b. Visita aos garimpos Na. Sá. Conceição, Bom Jesu e Cuiú-Cuiú. Rio de Janeiro, CPRM, 16 p.

Mayer, D.J.K.; Rigon, J.C.; Fonseca, L.R.; Gonçalez, R.; Hirata, W.K. 1990. Mina de ouro do Igarapé Bahia: Persistência de um prospecto. In: Congresso Brasileiro de Geologia, 36. Natal, 1990. Boletim Resumos...Natal, SBG. p. 135.

Meireles, E.M.; Teixeira, J.T.; Lourenço, R.S.; Medeiros Filho, C.A. 1982. Geologia, estrutura e mineralização aurífera de Serra Pelada. In: Congresso Brasileiro de Geologia, 32. Salvador, 1982. Anais... Salvador, SBG. v. 3, p. 900-911.

Meireles, E.M. \& Silva, A.R.B. 1988. Depósito de ouro de Serra Pelada, Marabá, Pará. In: Schobbenhaus C. \& Coelho C.E.S. Coords. Principais depósitos minerais do Brasil, Volume III. Metais básicos não-ferrosos, ouro e alumínio. Brasília, DNPM, p. 547-557.

Mello, E.F.; Xavier, R.P.; Tassinari, C.C.G. 1996. A review on the geochronology of the Rio Itapicuru greenstone belt, NE Bahia (Brazil), and the timing of the lode-gold deposits. In: Congresso Brasileiro de Geologia, 39. Salvador, 1996. Anais... Salvador, SBG. v. 7, p.273-276.

Milési, J.P.; Ledru, P.; Johan, V.; Marcoux, E.; Mougeot, R.; Lerouge, C.; Respaut, J.P ; Sabaté, P. 1996. Hydrothermal and metamorphic events related to the gold mineralizations hosted within detrital sediments in the Jacobina basin (Bahia Brazil). In: Congresso Brasileiro de Geologia, 39. Salvador, 1996. Anais... Salvador, SBG. v. 7, p. 218-220

Minter, W.E.L.; Renger, F.E.; Siegers, A. 1990. Early Proterozoic gold placers of the Moeda Formation within the Gandarela Syncline, Minas Gerais, Brazil. Economic Geology, 85:943-951.

Minter, W.E.L.; Renger, F.E.; Siegers, A. 1991. Archean or early Proterozoic gold placers of the Moeda Formation within the Gandarela Syncline, Minas Gerais, Brazil. In: Ladeira, E.A. ed. Brazil Gold '91. Rotterdam, A.A. Balkema. p. 513.

Misi, A.; Viveiros, P. V.S.; Lobato, L.M.; PedrosaSoares, A.C. 1993. Os depósitos minerais do Cráton do São Francisco e seu contexto geotectônico. In: Dominguez J.M.L. \& Misi A. eds. Cráton do São Francisco, Salvador, SBG. p. 187-215.

Molinari, L. \& Scarpelli, W. 1988. Depósitos de ouro de Jacobina, Bahia. In: Schobbenhaus C. \& Coelho C.E.S. Coords. Principais depósitos minerais do Brasil. Volume III. Metais básicos não-ferrosos, ouro e alumínio. Brasília, DNPM, p. 463-478

Monteiro, H.; Macedo, P.M.; Silva, M.D.; Moraes, A.A.; Marchetto, C.M.L . 1986. O greenstone belt do Alto Jauru. In: Congresso Brasileiro de Geologia, 34. Goiânia, 1986. Anais... Goiânia, SBG. v. 2, p. 630-646.

Monteiro, H.; Macedo, P.M.; Moraes, A.A.; Marchetto, C.M.L.; Fanton, J.J.; Magalhães, C.C. 1988. Depósito de ouro Cabaçal I, Mato Grosso. In: Schobbenhaus, C. \& Coelho, C.E.S. Coords. Principais depósitos minerais do Brasil. Volume III. Metais básicos não-ferrosos, ouro e alumínio. Brasília, DNPM, p. 535-545. 
Nascimento, J.A.S. \& Biagini, D.0.1988. Conhecimento atual da jazida de ouro de Lagoa Seca, sul do Pará. In: Congresso Brasileiro de Geologia, 35. Belém, 1988. Província Mineral de Carajás - Litoestratigrafia e principais depósitos minerais. Belém, SBG. p. $141-157$.

Oliveira, C.G. 1994. Deformação, metamorfismo, e mineralização aurífera no greenstone belt Sapucaia, Sudeste do Pará. Contexto geológico e mineralizações. In: Simpósio de Geologia da Amazônia, 4. Belém, 1994. Boletim de Resumos Expandidos.. Belém, SBG. p. 365-367.

Oreskes, N. \& Hitzman, M.W. 1993. A model for the origin of Olympic Dam-type deposits. In Kirkham, R.V. et al. eds. Mineral deposit modeling. Geol. Assoc. Can. Special. Paper 40, p. 615-633.

Pessoa, M.R.; Santiago, A.F.; Andrade, A.F.; Barreto, E.L.; Nascimento, J.O.; Oliveira, J.R.; Lopes, R.C.; Prazeres W.V. 1977. Projeto Jamanxim. Relatório Final. Manaus, CPRM / DNPM, Manaus, 3 v., 614 p.

Pinheiro, S.S. \& Reis, N.J. 1994. Os terrenos metavulcanossedimentares do Estado de Roraima. In: Simpósio de Geologia da Amazônia, 4. Belém, 1994. Boletim de Resumos Expandidos... Belém, SBG. p. 30-32.

Pires, F.R.M.; Gonçalves, F.T.T.; Ribeiro, L.A.S.; Siqueira, A.J.B. 1986. Controle das mineralizações auríferas do Grupo Cuiabá, Mato Grosso. In: Congresso Brasileiro de Geologia, 34. Goiânia, 1986. Anais... Goiânia, SBG. v. 5, p. 2383-2396.

Reischl, J.L. 1980. Mineralizações auríferas associadas ao complexo granítico de Lavras do Sul - RS. In: Congresso Brasileiro de Geologia, 31. Camboriú, 1980. Anais... Camboriú, SBG. v.3, p. 1700-1712.

Renger, F.E.; Silva, R.M.P.; Suckau, V.E. 1988. Ouro nos conglomerados da Formação Moeda, sinclinal de Gandarela, Quadrilátero Ferrífero, Minas Gerais. In: Congresso Brasileiro de Geologia, 35. Belém, 1988. Anais... Belém, SBG. v. 1, p. 4-57.

Ribeiro Rodrigues, L.C.R.; Friedrich, G.; Oliveira, C.G.; Vieira, F.W.R.; Biasi, E.E.; Callegari, L. A. 1996. The BIF-hosted Cuiabá gold deposit, Iron Quadrangle, Minas Gerais, Brazil: Characteristics, control and genesis. In: Congresso Brasileiro de Geologia, 39. Salvador, 1996. Anais... Salvador, SBG. v. 7, p. 224-228.

Robert, F. 1996. Tapajós gold project, Pará State, Brazil. Mission report. Part II: Geology of gold occurrences. Ottawa, Geol. Surv. Canada, $35 \mathrm{p}$.

Routhier, P. 1984. Where are the metals for the future? Orleans Cedex, BRGM, Cap. 3, p. 36-49.

Sá, E.L. 1990. Tipologia e controle estrutural das mineralizações aurífera das minas Cauê e Conceição de Itabira / Minas Gerais. In: Congresso Brasileiro de Geologia, 36. Natal, 1990. Boletim Resumos...Natal, SBG. p. 148-149.

Sachs, L.L.B. \& Batista, J.J. 1994. O magmatismo associado ao depósito mineral crupro-aurífero do Igarapé Bahia, Carajás, Pará, Brasil. In: Congresso Brasileiro de Geologia, 38. Camboriú, 1994. Boletim de Resumos Expandidos... Camboriú, SBG. v.1, p. 306-307.

Saes, G.S.; Pinho, F.E.C.; Leite, J.A.D. 1991. Coberturas metassedimentares do Proterozóico médio no sul do Cráton Amazônico e suas mineralizações auríferas. In: Simpósio de Geologia do Centro-Oeste, 3. Cuiabá, 1991. Anais... Cuiabá, SBG. p. 37-47.

Santos, D.B.; Fernandes, P.E.C.A.; Dreher, A.M.; Cunha, F.M.B.; Basei, M.A.S.; Teixeira, J.B.G. 1975. Projeto RADAM. Folha SB.21 Tapajós. Geologia. Rio de Janeiro, DNPM, p. 15-99.

Santos, J.F. 1984. O ouro elúvio-laterítico de Jatobá - MT. In: Congresso Brasileiro de Geologia, 33. Rio de Janeiro, 1984. Anais... Riode Janeiro, SBG. v. 8, p. 4012-4023.

Santos, J.O.S. \& Reis, N.J. 1992. Uso multidisciplinar de sensores remotos no setor ocidental de Roraima - Brasil. In: Congresso Brasileiro de Geologia, 37. São Paulo, 1992. Anais... São Paulo, SBG. v. 1, p. 137-138.

Santos, M.D.; Leonardos, O.H.; Zimmermann, E.J. 1994. Sistema de fluídos e modelo genético do depósito aurífero do Cumaru, SE do Estado do Pará. Contexto geológico e mineralizações. In: Simpósio de Geologia da Amazônia, 4. Belém, 1994. Boletim de Resumos Expandidos...Belém, SBG. p. 375-378.

Santos, O.M.; Vitorasso, E.C.L.; Silva, R.M.; Guerra, H.R.M.; Chaves, J.L.; Mantovani, T.J.; Silva, R.A.; Kalil Jr., A.R.; Santos, V.A.M.; Navarro, L.A.G.; Pena, L.S.T. 1988. Mina de ouro de Fazenda Brasileiro, Bahia. In: Schobbenhaus, C. \& Coelho, C.E.S. Coords. Principais depósitos minerais do Brasil, Volume III. Metais básicos não-ferrosos, ouro e alumínio. Brasília, DNPM, p. 431-444.

Santos, R. A. 1996. Contribuição à análise estrutural de jazimentos auríferos do rio Tapajós. SW do Pará. Garimpos Chico Torres, São José, Mamoal e Jutaí. Salvador, CPRM, $25 \mathrm{p}$.

Santos, R. A. 1997. Contribuição à análise estrutural de jazimentos auríferos do rio Tapajós, SW do Pará e SE do Amazonas. Garimpos Abacaxis, Espírito Santo, Bom Jesus, Goiano, Fazenda Pison, Ouromil, Santa Isabel, Majestade e Carneirinho. Salvador, CPRM, $36 \mathrm{p}$

Saueressig, R. 1988. Depósito de cobre e zinco do Corpo Quatro, Pojuca. In: Congresso Brasileiro de Geologia, 35. Belém, 1988. Província Mineral de Carajás -Litoestratigrafia e principais depósitos minerais. Belém, SBG. p. 113-119.

Scarpelli, W. 1991. Aspects of gold mineralization in the Iron Quadrangle, Brazil. In: Ladeira, E.A. ed. Brazil Gold '91. Rotterdam, A.A. Balkema. p. 151-157.

Schobbenhaus, C. \& Campos, D.A. (1984). A evolução da Plataforma Sulamericana no Brasil e suas principais concentrações minerais. In: Schobbenhaus C. et al. Coords. Geologia do Brasil. Brasília, DNPM, p. 9-53.

Sillitoe, R. H. 1991. Intrusion-related gold deposits. In: Foster R.P. ed. Gold metallogeny and exploration. Glasgow, Blackie, p. 165-209.

Silva, A.R.B. 1984. Províncias auríferas do Estado do Pará e Território Federal do Amapá In: Congresso Brasileiro de Geologia, 33. Rio de Janeiro, 1984. Anais... Rio de Janeiro, SBG. v. 8, p. 3945-3958.

Silva, A.R.B. \& Cordeiro, A.A.C. 1988. Depósitos de ouro da Serra das Andorinhas, Rio Maria, Pará. In: Schobbenhaus C. \& Coelho C.E.S. Coords. Principais depósitos minerais do Brasil. Volume III. Metais básicos não-ferrosos, ouro e alumínio. Brasília, DNPM, p. 559-567.

Silva, C.M.G. \& Villas, R.N.N. 1996. Alteração hidrotermal em arenitos e sills gabróicos arqueanos associada à mineralização sulfetada do Prospecto Águas Claras, Serra dos Carajás (PA). In: Congresso Brasileiro de Geologia, 39. Salvador, 1996. Anais... Salvador, SBG. v.3, p. 227-229.
Silva, C.R. \& Rizzoto, G.J. 1994. Província Aurífera Guaporé. In: Congresso Brasileiro de Geologia, 38. Camboriú, 1994. Boletim de Resumos Expandidos... Camboriú, SBG. v. 1, p. 323-325.

Silva, G.H.; Leal, J.W.L.; Salum, O.A.L.; Dall'Agnol, R.; Basei, M.A.S. 1974. Esboco geológico de parte da Folha SC.21 Juruena. In: Congresso Brasileiro de Geologia, 28. Porto Alegre, 1974. Anais... Porto Alegre, SBG. v. 4, p. 309-320.

Silva, G.L.P. \& Xavier, R.P. 1996. The gold-carbonaceous matter association in lode deposits of the Rio Itapicuru greenstone belt, NE Brazil. In: Congresso Brasileiro de Geologia, 39. Salvador, 1996. Anais... Salvador, SBG. v. 7, p. 284-287.

Silva, J.A. \& Sá, J.A.G. 1988. Jazida de cobre de Chapada, Mara Rosa, Goiás. In: Schobbenhaus C. \& Coelho C.E.S. Coords. Principais depósitos minerais do Brasil. Volume III. Metais básicos não-ferrosos, ouro e alumínio. Brasília, DNPM, p. 55-60.

Soares, V.S.; Santos, A.B.; Vieira, E.A.; Bella, V.M.; Martins, L.P.B. 1994. Área Águas Claras: Contexto geológico e mineralizações. In: Simpósio de Geologia da Amazônia, 4. Belém, 1994. Boletim de Resumos Expandidos... Belém, SBG. p. 379-382.

Souza, N.B. 1988. Principais depósitos de ouro do Estado de Mato Grosso. In: Congresso Brasileiro de Geologia, 35. Belém, 1988. Anais... Belém, SBG. v. 1, p.1 16-129.

Teixeira, G. \& Gonzalez, M. 1988. Minas do Camaquã, município de Caçapava do Sul, RS. In: Schobbenhaus, C. \& Coelho, C.E.S. Coords. Principais depósitos minerais do Brasil. Volume III. Metais básicos não-ferrosos, ouro e alumínio. Brasília, DNPM, p. 33-41.

Teixeira, J.B.G.; Kishida, A.; Marimon, M.P.C.; Xavier, R.P.; McReath, I. 1990. The Fazenda Brasileiro gold deposit, Bahia: Geology, hydrothermal alteration, and fluid inclusion studies. Economic Geology, 85:990-1009.

Teixeira, N. A. \& Kuyumjian, R.M. 1991. The Mateus Leme -Pitangui hydrothermal zone: Do they represent a fossil hot spring system in the Rio das Velhas greenstone belt, Central Brazil? In Ladeira, E.A. ed. Brazil Gold '91. Rotterdam, A.A. Balkema. p. 171-177.

Thomson, M.L. \& Fyfe, W.S. 1990. The Crixas gold deposit, Brazil: Thrust-related, postpeak metamorphic gold mineralization of possible Brasiliano Cycle age. Economic Geology, 85:928-942

Thorman, C.H.; Hitzman, M.W. Hitzman, M.W.; Drew, L.J. 1996. new ideas regarding the origin and tectonic setting of mineral deposits (Morro Agudo $\mathrm{Zn}-\mathrm{Pb}$ and Morro do Ouro $\mathrm{Au}$ ) in the Paracatu-Vazante fold belt, Minas Gerais. In: Congresso Brasileiro de Geologia, 39. Salvador, 1996. Anais... Salvador, SBG. v.3, p. 344-346.

Toniolo, J.A. \& Costa, A.F.U. 1994. Prospecção de ouro na área de Canelinha, Santa Catarina. In: Congresso Brasileiro de Geologia, 38. Camboriú, 1994. Boletim de Resumos Expandidos... Camboriú, SBG. v. 2, p. 200-201.

Toniolo, J.A. \& Kirchner, C.A. 1994. Mineralizações de ouro no RS E SC. In: Congresso Brasileiro de Geologia, 38. Camboriú, 1994. Boletim de Resumos Expandidos. Camboriú, SBG. v. 2, p. 172-174

Uhlein, A.; Assis, L.C.; Dardenne, M.A. 1983. As mineralizações de ouro e cromita da seqüência vulcano-sedimentar de Serro - MG. In: Simpósio de Geologia de Minas Gerais, 2. Belo Horizonte, 1985. Anais...Belo Horizonte, SBG. p. 306-320.

Uhlein, A.; Chaves, M.S.C.; Dossin, I.A. 1986. Recursos minerais da serra do Espinhaço Meridional (MG): uma síntese baseada no contexto litoestatigráfico regional. In Congresso Brasileiro de Geologia, 34. Goiânia, 1986. Anais... Goiânia, SBG. v. 5 p. $2453-2464$.

Veiga, A.T.C. 1985. Geologia da Província aurifera do Cassiporé - Amapá. In: Simpósio de Geologia da Amazônia, 2. Belém, 1985. Anais...Belém, SBG. v. 3, p. 135-146.

Veiga, A.T.C. 1988 . Mina de ouro de Novo Planeta, Alta Floresta, Mato Grosso. In: Schobbenhaus C. \& Coelho C.E.S. Coords. Principais depósitos minerais do Brasil, Volume III. Metais básicos não-ferrosos, ouro e alumínio. Brasília, DNPM, p. 569-580

Vial, D.S. 1988. Mina de ouro da Passagem, Mariana, Minas Gerais. In: Schobbenhaus C. \& Coelho C.E.S. Coords. Principais depósitos minerais do Brasil. Volume III. Metais básicos não-ferrosos, ouro e alumínio. Brasília, DNPM, p. 421-430.

Vieira, E.A.P. Saueressig, R. Siqueira, J.B.; Silva, E.R.P.; Rego, J.L. Castro, F.D.C. 1988 Caracterização geológica da jazida polimetálica do Salobo 3A. In: Congresso Brasileiro de Geologia, 35. Belém, 1988. Anexo Província Mineral de Carajás Litoestratigrafia e principais depósitos minerais. Belém, SBG. p. 95-111.

Vieira, F.W.R. \& Oliveira, G.A.I. 1988. Geologia do Distrito Aurífero de Nova Lima, Minas Gerais. In: Schobbenhaus C. \& Coelho C.E.S. Coords. Principais depósitos minerais do Brasil. Volume III. Metais básicos não-ferrosos, ouro e alumínio. Brasília, DNPM, p. 377-391.

Viveiros, J.F.M. 1991. Novos Projetos de Ouro da CVRD. Riacho dos Machados, Maria Preta e Igarapé Bahia. Projeto Riacho dos Machados. In: Simpósio Internacional do Ouro, 7. Rio de Janeiro, $7 \mathrm{p}$.

White, N.C. \& Hedenquist, J.W. 1990. Epithermal environments and styles of mineralization: variations and their causes, and guidelines for exploration. Journal Geochemical Exploration, 36:445-474.

Xavier, R.P. \& Foster, R.P. 1991. The role of carbonaceous shear bands in fluid -flow and gold-precipitation in the Fazenda Maria Preta mine, Bahia, northeast Brazil. In Ladeira, E.A. ed. Brazil Gold '91. Rotterdam, A.A. Balkema. p. 269-277.

Yamaoka, W.N. \& Araújo, E.M. 1988. Depósito de ouro de "Mina'TII, Crixás, Goiás. In: Schobbenhaus C. \& Coelho C.E.S. Coords. Principais depósitos minerais do Brasil. Volume III. Metais básicos não-ferrosos, ouro e alumínio. Brasília, DNPM, p. 491-498.

Yokoi, O.Y. 1994. Garimpo do Juruena/MT -Controles da mineralização aurífera. In: Congresso Brasileiro de Geologia, 38. Camboriú, 1994. Boletim de Resumos Expandidos... Camboriú, SBG. v. 1, p. 158-159.

Zini, A.; Forlim, R.; Andreazza, P.; Souza, A. 1988. Depósito de ouro do Morro do Ouro, Paracatu, Minas Gerais. In: Schobbenhaus, C. \& Coelho, C.E.S. Coords. Principais depósitos minerais do Brasil. Volume III. Metais básicos não-ferrosos, ouro e alumínio. Brasília, DNPM, p. 479-489.

Manuscrito A-957 Recebido 26 de fevereiro de 1998 Revisão do autor em 15 de maio de 1998
Reviata em 15 de junho de 1998 